\title{
Genital chlamydial infection among women in Nicaragua: validity of direct fluorescent antibody testing, prevalence, risk factors and clinical manifestations
}

\author{
Björn Herrmann, Felix Espinoza, Rosaura Rivera Villegas, George Davey Smith, Angela \\ Ramos, Matthias Egger
}

Objective: To validate the performance of a direct fluorescence antibody (DFA) test and to determine the prevalence, risk factors and clinical manifestations of cervical chlamydia infection in different groups of women in Nicaragua.

Study population: 926 women, 863 routine clinic attenders (mean age 27 years) and 63 sex workers (mean age 25 years) attending health centres in León, Corinto, Matagalpa and Bluefields.

Methods: Cervical specimens were examined using the Syva MicroTrak test system with a cutoff of 10 or more elementary bodies (EBs). The DFA results were validated by a one-step polymerase chain reaction (PCR) assay. Discordant results were further examined in nested PCR assays directed at two different target genes. An interviewer-administered questionnaire and a standard gynaecological examination were completed.

Results: Sensitivity of DFA was $80 \cdot 1 \%$, specificity $98 \cdot 3 \%$, and positive and negative predictive values $62.5 \%$ and $99.3 \%$, respectively. Values were lower in locations where samples thawed because of electricity breaks and higher among sex workers. The majority of discordant results was confirmed as positive in nested PCR assays. Prevalence of cervical chlamydia infection based on positivity in DFA and/or PCR ranged from $2 \%$ among routine clinic attenders aged 35 years or older, to $8 \%$ among adolescent clinic attenders, and to $14 \%$ among sex workers. Among routine clinic attenders, young age (odds ratio [OR] 3.6, 95\% confidence intervals [95\% CI] $1.4-8.9$ for women aged 15-19 years as compared with 1 in women 25 years of age or older) and use of oral contraceptives (OR $4 \cdot 0,95 \%$ CI $1 \cdot 7-9 \cdot 6$ ) were the only statistically significant risk factors identified in multivariate logistic regression analysis. Presence of mucopurulent cervical discharge (OR 5.9, 95\% CI 3.0-11.5) and presence of ectropion (OR $2 \cdot 6,95 \%$ CI $1 \cdot 1-6 \cdot 5$ ) were the clinical signs independently associated with infection.

Department of Infectious Diseases and Clinical Microbiology, University of Uppsala, Sweden

B Herrmann

Department of

Microbiology, National

Autonomous

University (UNAN)

León, Nicaragua

F Espinoza

Health Centre

"Gaspar Garcia

Laviana", Corinto,

Nicaragua

R Rivera Villegas

Department of Social

Medicine, University

of Bristol, Bristol, UK

$G$ Davey Smith

Department of

Microbiology, National

Autonomous

University (UNAN)

Managua, Nicaragua

A Ramos

Department of Social and Preventive Medicine, University of Berne, Switzerland $M$ Egger

Address correspondence to: Dr Matthias Egger, Department of Social and Preventive Medicine University of Berne, Finkenhubelweg 11, CH3012 Bern, Switzerland.

Accepted for publication 14 September 1995

Conclusions: Our results indicate that the DFA test was sensitive and specific while the performance of the PCR assay depends on adequate storage of samples. Genital C trachomatis infection is a common health problem among women in Nicaragua. The wide implementation of syndromic STD management algorithms together with health education programmes aimed at young people is the most promising approach to control STD in Nicaragua.

(Genitourin Med 1996;72:20-26)

Keywords: Chlamydia trachomatis; women; direct immunofluorescence testing; polymerase chain reaction; risk factors; Nicaragua

\section{Introduction}

Infection by Chlamydia trachomatis is a common sexually transmitted disease (STD) both in industrialised and developing countries. ${ }^{12}$ In women, the organism can cause urethritis and cervicitis, but up to $70 \%$ of infections are asymptomatic. ${ }^{3}$ Pelvic inflammatory diseaseendometritis and salpingitis-may develop if the infection remains untreated and can lead to infertility, ectopic pregnancy and chronic abdominal pain. ${ }^{2}$ Neonates delivered vaginally from infected mothers may contract chlamydial conjunctivitis or pneumonia. In men, infection can cause urethritis and epididymitis, but $25 \%$ to $50 \%$ of infected men remain asymptomatic. ${ }^{4}$

The awareness of genital chlamydial infections in developing countries is still limited. At district level, diagnostic facilities are generally unavailable. In larger centres, diagnosis is predominantly based on first generation enzyme immuno assays (EIA) which are known to have suboptimal sensitivities, ${ }^{5}$ or on culture with outdated staining techniques such as Giemsa or iodine. More recently, the introduction of direct fluorescent antibody (DFA) tests has improved the detection of the organism in a number of settings. Together with other non-culture based tests, the DFA method is valuable for examination of specimens that have lost viable chlamydia through prolonged transport or inadequate storage. ${ }^{5}$ The DFA test can be very sensitive; however, its performance is highly observer-dependent. ${ }^{5}$ Validation of DFA findings is therefore required for clinical and epidemiological research both in industrialised and developing countries. Polymerase chain reaction (PCR) is a non-culture test system whose sensitivity and specificity for detection of genital chlamydia infection is comparable or even better than cell culture ${ }^{67}$ It is therefore well suited for evalua- 
tion of DFA in a less developed country lacking the facilities for culture.

Genital chlamydia infections have not been studied so far in Nicaragua. Data for other Central American countries are also scarce. In order to determine prevalence and risk factors of genital $C$ trachomatis infections, we conducted a study among women attending routine clinics and sex workers attending special clinics in health centres in different regions of Nicaragua. Here we describe the performance of the locally performed DFA tests in comparison with PCR analysis in a Swedish laboratory, and the prevalence, risk factors and clinical presentation of the infection among Nicaraguan women.

\section{Materials and methods \\ Study population}

Women aged 15 to 45 years attending gynaecological, cervical screening (Papanicolau smear), antenatal, or family planning clinics located at public health centres in the municipalities of León, Bluefields and Matagalpa, and female sex workers from the ports of Corinto and Bluefields participated in this study. The study locations, shown on the map (Fig), cover the densely populated Pacific coast (León, Corinto), the central mountainous region (Matagalpa) and the ethnically diverse Atlantic coast (Bluefields). The study started in León in March 1992 and concluded in Matagalpa in June 1993. In each location women were recruited during a period of

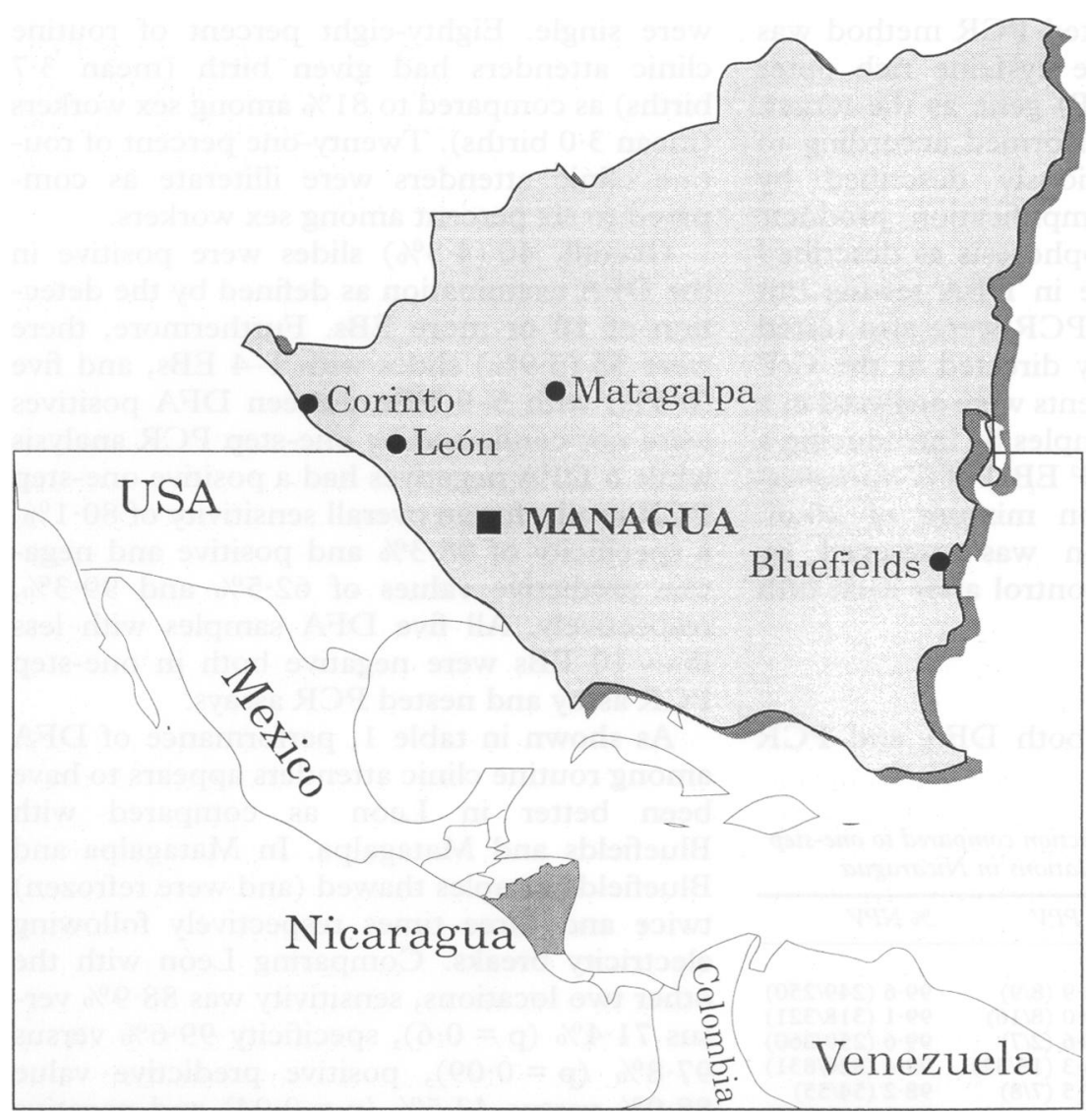

Map of Nicaragua indicating the four study locations and the capital Managua. Routin clinic attenders were examined in Leon, Matagalpa and Bluefields and sex workers in Corinto and Bluefields about four months. For health centre attenders, the sample size envisaged at each study site was around 300 women. Sex workers were examined at special clinics which were set up within the framework of an STD and acquired immunodeficiency syndrome (AIDS) prevention programme in Corinto and Bluefields. ${ }^{8}$ The women were from urban settings except for Matagalpa where exclusively women from coffee growing farms participated. Consecutive women attending the clinics were included after giving verbal consent. An interviewer-administered standardised questionnaire and a standard gynaecological examination was then completed and specimens were collected. This included two cervical swabs for the diagnosis of chlamydia and gonorrhoea, and a vaginal swab for a wet mount preparation. All women received free treatment and counselling if a sexually transmitted infection was diagnosed. Women with positive DFA results were traced by a nurse for this purpose as soon as the result became available.

\section{Specimen collection and DFA testing}

A non-lubricated speculum was passed and the cervix cleaned with a cotton-tipped swab. An endocervical specimen was then taken with a non-toxic calcium alginate swab (ENT, Medical Wire \& Co, UK) and rolled onto a 6$\mathrm{mm}$ slide well before placing it into a cryotube with sucrose phosphate buffered saline transport media for testing by PCR. Slides for DFA tests were fixed in methanol and stored up to 3 weeks at $+8^{\circ} \mathrm{C}$ before staining with monoclonal antibodies according to the instructions of the manufacturer (MicroTrak, Syva, USA). A slide was considered positive if 10 or more EBs were detected upon examination. All slides were examined by a single laboratory technician who was trained by one of us $(\mathrm{BH})$. A standard Zeiss microscope fitted with a fluorescence condenser type IVFI was used with $400 \times$ magnification for reading. Specimens were considered inadequate if they contained less than 10 epithelial cells, or if the smear was too thick for individual cells to be brought into focus.

\section{Storage and transport}

The swabs for PCR analysis were kept in a cool box at $+8^{\circ} \mathrm{C}$ up to six hours before being frozen at $-70^{\circ} \mathrm{C}$ (León, Corinto) or $-20^{\circ} \mathrm{C}$ (Bluefields, Matagalpa). In Matagalpa and Bluefields, samples thawed and were refrozen on up to three occasions following electricity cuts. After conclusion of the study, samples were transported by air in a cool box at $+8^{\circ} \mathrm{C}$ until being frozen at $-20^{\circ} \mathrm{C}$ on arrival in Uppsala.

\section{$P C R$ analysis}

Nucleic acid for one-step PCR analysis was prepared from $200 \mu \mathrm{l}$ volume of each specimen, centrifuged at $12,000 \mathrm{~g}$ for 20 minutes and suspended in $20 \mu \mathrm{l}$ lysis buffer $(10 \mathrm{mM}$ Tris- $\mathrm{HCl}, \mathrm{pH} 7 \cdot 5,1 \mathrm{mM}$ EDTA, $1 \%$ Triton $\mathrm{X}-100$ and $200 \mu \mathrm{g}$ proteinase $\mathrm{K}$ per $\mathrm{ml}$ ). After incubation at $60^{\circ} \mathrm{C}$ for one hour and $95^{\circ} \mathrm{C}$ for 10 minutes, PCR amplification was performed 
according to the method of Ossewarde et $a l^{9}$ on a $2 \mu \mathrm{l}$ lysate in $20 \mu \mathrm{l}$ reaction mixture. The latter contained $0.4 \mu \mathrm{M}$ oligonucleotide primer and $1.0 \mathrm{U}$ of Taq-polymerase (Boehringer-Mannheim). The $493 \mathrm{bp}$ fragment from the cryptic $C$ trachomatis plasmid was detected after electrophoresis on $1.0 \%$ agarose gel stained with ethidium bromide under UV-light. Two positive controls with $10^{2}$ and $10^{4} \mathrm{EBs}$, respectively, and a negative control were included in each run. The laboratory technician performing the one-step PCR tests was blind to the DFA results.

Samples positive by DFA but negative in the one-step PCR were further analysed by a nested PCR assay including the $C$ trachomatis specific inner primer pair Pd3 (5'GGCCTCTAAACAGGCTAGAGCG3') and Pd4 (5'TTCGTCTAACTTACGGATCCCTTG3'). The selected set amplified a fragment of 259 bp from nucleotide 6862 to nucleotide 7121 of the plasmid of serovar L2. ${ }^{10}$ After preparing a new nucleic acid sample and amplification with the outer primer pair Pd1 and Pd2, $1 \mu 1$ was transferred to $50 \mu \mathrm{l}$ of a new reaction mixture containing $0.4 \mu \mathrm{M}$ oligonucleotide $\mathrm{Pd} 3$ and $\mathrm{Pd} 4,200 \mu \mathrm{M}$ nucleotides, $2.0 \mathrm{mM}$ $\mathrm{MgCl} 2,10 \mathrm{mM}$ Tris- $\mathrm{HCl}$ (pH 8.3), $50 \mathrm{mM}$ $\mathrm{KCl}$, and 1.0 U Taq-polymerase (BoehringerMannheim). The samples were subjected to a denaturation step at $95^{\circ} \mathrm{C}$ for 3 minutes in a Perkin-Elmer 9600 thermocycler followed by 30 cycles of amplification, consisting of 30 seconds at $95^{\circ} \mathrm{C}, 1$ second at $60^{\circ} \mathrm{C}$ and $45 \mathrm{sec}$ onds at $72^{\circ} \mathrm{C}$. Amplification was completed by extension at $72^{\circ} \mathrm{C}$ for 5 minutes. To confirm samples positive in both DFA and the nested plasmid PCR analysis and exclude false positive cases, a second nested PCR method was introduced by using the cysteine rich outer membrane proteine ( $\mathrm{CrP}$ ) gene as the target. This PCR assay was performed according to the amplification previously described by Wahlberg et $a l^{11}$ but amplification products were detected by electrophoresis as described above. Samples negative in DFA testing but positive in the one-step PCR were also tested in the nested PCR assay directed at the $\mathrm{CrP}$ gene. Inhibitory components were analysed in a subset of 168 clinical samples by introducing a weak positive control ( $\left.10^{2} \mathrm{EBs}\right)$ of $C$ trachomatis DNA in the reaction mixture of $20 \mu \mathrm{l}$. Amplicon contamination was surveyed by inclusion of a negative control after each fifth clinical sample.

Statistical analysis

Only women who had both DFA and PCR

Table 1 Performance of DFA testing for genital Clamydia infection compared to one-step polymerase chain reaction analysis among different female populations in Nicaragua

\begin{tabular}{lllll}
\hline Population & $\%$ sensitivity & $\%$ specificity & $\% P P V$ & $\%$ NPV \\
\hline Routine clinic attenders & & & & \\
$\quad$ León & $88 \cdot 9(8 / 9)$ & $99 \cdot 6(249 / 250)$ & $88 \cdot 9(8 / 9)$ & $99 \cdot 6(249 / 250)$ \\
Bluefields & $72 \cdot 7(8 / 11)$ & $97 \cdot 5(318 / 326)$ & $50 \cdot 0(8 / 16)$ & $99 \cdot 1(318 / 321)$ \\
Matagalpa & $66 \cdot 7(2 / 3)$ & $98 \cdot 1(259 / 264)$ & $28 \cdot 6(2 / 7)$ & $99 \cdot 6(259 / 260)$ \\
Combined & $78 \cdot 3(18 / 23)$ & $98 \cdot 3(826 / 840)$ & $56 \cdot 3(18 / 32)$ & $99 \cdot 4(826 / 831)$ \\
Sex workers & $87 \cdot 5(7 / 8)$ & $98 \cdot 2(54 / 55)$ & $87 \cdot 5(7 / 8)$ & $98 \cdot 2(54 / 55)$ \\
All women & $80 \cdot 1(25 / 31)$ & $98 \cdot 3(880 / 895)$ & $62 \cdot 5(24 / 40)$ & $99 \cdot 3(880 / 886)$ \\
\hline
\end{tabular}

Percentage (numbers)

PPV: positive predictive value. NPV: negative predictive value. exams done and whose DFA sample was considered adequate by the microscopist were included in the analysis. Sensitivity, specificity and positive and negative predictive values were then calculated, taking the one-step PCR results as the gold standard. For the assessment of the prevalence of genital chlamydial infections, women positive in only one test were considered to be infected. Comparisons between groups employed chi-square tests (with continuity correction when appropriate) and student's $t$ tests. Multivariate logistic regression models were also calculated. Results are presented as percentages, means and odds ratios with $95 \%$ confidence intervals.

\section{Results}

In the routine outpatient clinics, a total of 1038 women were examined but only 951 (92\%) had their sample analysed both by DFA and PCR. Among the latter, an adequate DFA sample had been collected in 863 women $(90 \%)$. In addition, a total of 67 female sex workers were examined at the special clinics, $100 \%$ of whom had both analyses done. The quality of the samples was inadequate in four sex workers. Therefore, 863 women attending routine clinics (259 from León, 267 from rural Matagalpa and 337 from Bluefields) and 63 female sex workers (42 from Corinto and 21 from Bluefields) were included in the present analysis, for a total of 926 women. Mean age was $27 \cdot 3$ years among routine clinic attenders as compared with $25 \cdot 6$ among sex workers. At the routine clinics the majority of women were either married $(30 \%)$ or lived in free union (53\%) whereas most of sex workers $(79 \%)$ were single. Eighty-eight percent of routine clinic attenders had given birth (mean 3.7 births) as compared to $81 \%$ among sex workers (mean 3.0 births). Twenty-one percent of routine clinic attenders were illiterate as compared to six percent among sex workers.

Overall, $40(4 \cdot 3 \%)$ slides were positive in the DFA examination as defined by the detection of 10 or more EBs. Furthermore, there were $55(5.9 \%)$ slides with 1-4 EBs, and five $(0.5 \%)$ with 5-9 EBs. Fifteen DFA positives were not confirmed by one-step PCR analysis while $6 \mathrm{DFA}$ negatives had a positive one-step PCR result, for an overall sensitivity of $80 \cdot 1 \%$, a specificity of $98.3 \%$ and positive and negative predictive values of $62.5 \%$ and $99.3 \%$, respectively. All five DFA samples with less than $10 \mathrm{EBs}$ were negative both in one-step PCR assay and nested PCR assays.

As shown in table 1, performance of DFA among routine clinic attenders appears to have been better in León as compared with Bluefields and Matagalpa. In Matagalpa and Bluefields samples thawed (and were refrozen) twice and three times respectively following electricity breaks. Comparing León with the other two locations, sensitivity was $88.9 \%$ versus $71.4 \%(p=0.6)$, specificity $99.6 \%$ versus $97.8 \%(\mathrm{p}=0.09)$, positive predictive value $88.9 \%$ versus $43.5 \%(p=0.04)$ and negative predictive value $99 \cdot 6 \%$ versus $99 \cdot 3 \%$ ( $p=$ $0 \cdot 9)$. Performance among sex workers was also 
Table 2 Risk factors for genital Chlamydia infection among 863 women attending routine clinics

\begin{tabular}{|c|c|c|c|}
\hline & $\begin{array}{l}\text { \% Prevalence } \\
\text { (numbers) }\end{array}$ & $\begin{array}{l}\text { Odds ratio } \\
(95 \% \text { CI) }\end{array}$ & $p$ \\
\hline $\begin{array}{l}\text { Age (years) } \\
<20 \\
20-24 \\
\geqslant 25\end{array}$ & $\begin{array}{l}8 \cdot 0(10 / 125) \\
6 \cdot 7(16 / 239) \\
2 \cdot 2(11 / 499)\end{array}$ & $\begin{array}{l}3.6(1.4-8.9) \\
2.6(1.1-5.9) \\
1.0\end{array}$ & 0.01 \\
\hline $\begin{array}{l}\text { Marital status } \\
\text { Single } \\
\text { Free union } \\
\text { Married }\end{array}$ & $\begin{array}{l}4 \cdot 9(7 / 143) \\
5 \cdot 1(23 / 454) \\
2 \cdot 7(7 / 256)\end{array}$ & $\begin{array}{l}2 \cdot 2(0 \cdot 7-4 \cdot 3) \\
1 \cdot 8(0 \cdot 7-4 \cdot 3) \\
1 \cdot 0\end{array}$ & 0.3 \\
\hline $\begin{array}{l}\text { Clinical location } \\
\text { Bluefields } \\
\text { León } \\
\text { Rural Matagalpa }\end{array}$ & $\begin{array}{l}5.3(18 / 337) \\
3.0(10 / 259) \\
3.4(9 / 267)\end{array}$ & $\begin{array}{l}1.5(0.6-3 \cdot 8) \\
0.8(0.3-2 \cdot 4) \\
1.0\end{array}$ & 0.3 \\
\hline $\begin{array}{l}\text { Type of clinic } \\
\text { Gynecological } \\
\text { Papanicolau } \\
\text { Family planning } \\
\text { Prenatal control }\end{array}$ & $\begin{array}{l}3 \cdot 8(12 / 313) \\
4 \cdot 1(8 / 195) \\
3 \cdot 5(5 / 145) \\
5 \cdot 7(12 / 210)\end{array}$ & $\begin{array}{l}0.6(0 \cdot 2-1 \cdot 6) \\
0 \cdot 8(0 \cdot 3-2 \cdot 1) \\
0 \cdot 5(0 \cdot 2-1 \cdot 8) \\
1 \cdot 0\end{array}$ & 0.7 \\
\hline $\begin{array}{l}\text { Oral contraception } \\
\text { Yes } \\
\text { No }\end{array}$ & $\begin{array}{r}10.9(11 / 101) \\
3.4(26 / 762)\end{array}$ & $\begin{array}{l}4 \cdot 0(1 \cdot 7-9 \cdot 6) \\
1 \cdot 0\end{array}$ & 0.002 \\
\hline $\begin{array}{l}\text { Intrauterine device } \\
\text { Yes } \\
\text { No }\end{array}$ & $\begin{array}{l}1 \cdot 8(2 / 111) \\
4 \cdot 7(35 / 752)\end{array}$ & $\begin{array}{l}0.6(0 \cdot 1-3 \cdot 0) \\
1.0\end{array}$ & 0.6 \\
\hline $\begin{array}{l}\text { History of STD } \\
\text { Yes } \\
\text { No }\end{array}$ & $\begin{array}{l}6 \cdot 2(12 / 193) \\
3 \cdot 7(25 / 669)\end{array}$ & $\begin{array}{l}0.5(0 \cdot 2-1 \cdot 1) \\
1.0\end{array}$ & 0.09 \\
\hline $\begin{array}{l}\text { Literacy } \\
\text { Illiterate } \\
\text { Literate }\end{array}$ & $\begin{array}{l}3.9(7 / 181) \\
4.4(30 / 682)\end{array}$ & $\begin{array}{l}1 \cdot 3(0 \cdot 5-3 \cdot 3) \\
1.0\end{array}$ & 0.6 \\
\hline $\begin{array}{l}\text { Housing conditions } \\
\text { (No. of inhabitants/room) } \\
>3 \\
2 \cdot 1-3 \\
1-2\end{array}$ & $\begin{array}{l}4 \cdot 3(17 / 399) \\
5 \cdot 1(12 / 234) \\
3 \cdot 1(6 / 195)\end{array}$ & $\begin{array}{l}1.4(0.6-3.4) \\
1.5(0.6-3.9) \\
1.0\end{array}$ & 0.9 \\
\hline
\end{tabular}

95\% CI: $95 \%$ confidence interval. STD: sexually transmitted disease.

Odds ratio of 1.0 indicate reference category. Odds ratios and $p$ values from multivariate logistic regression model adjusting for all variables listed. Data missing in up to ten women.

better than among the routine clinic attenders examined outside León.

Fourteen out of 15 DFA positive, but onestep PCR negative, tests could be further examined in nested PCR assays. One sample had to be excluded because of insufficient material. Ten out of 14 were positive while the other four samples remained negative in both nested assays. All six DFA negative but onestep PCR positives were confirmed as positive in the nested PCR assay directed at the $\mathrm{CrP}$ gene. Therefore, 16 out of 20 discordant samples $(80 \%)$ were confirmed as positive in nested assays. Taking these results into account would considerably improve the fig-

Table 3 Clinical signs associated with genital Chlamydia infection

\begin{tabular}{|c|c|c|c|}
\hline & $\begin{array}{l}\% \text { Prevalence } \\
\text { (numbers) }\end{array}$ & $\begin{array}{l}\text { Odds ratio } \\
(95 \% \text { CI) }\end{array}$ & $p$ \\
\hline $\begin{array}{l}\text { Vaginal discharge } \\
\text { Present } \\
\text { Absent }\end{array}$ & $\begin{array}{l}5 \cdot 5(35 / 639) \\
3 \cdot 9(11 / 282)\end{array}$ & $\begin{array}{l}1 \cdot 1(0 \cdot 5-2 \cdot 1) \\
1 \cdot 0\end{array}$ & 0.9 \\
\hline $\begin{array}{l}\text { Mucopus in cervix } \\
\text { Present } \\
\text { Absent }\end{array}$ & $\begin{array}{r}15 \cdot 2(23 \cdot 151) \\
3 \cdot 0(23 / 771)\end{array}$ & $\begin{array}{l}5.9(3.0-11.5) \\
1.0\end{array}$ & 0.0001 \\
\hline $\begin{array}{l}\text { Oedema of cervix } \\
\text { Present } \\
\text { Absent }\end{array}$ & $\begin{array}{l}5 \cdot 5(17 / 308) \\
4 \cdot 7(29 / 614)\end{array}$ & $\begin{array}{l}0.5(0.3-1.1) \\
1.0\end{array}$ & $0 \cdot 11$ \\
\hline $\begin{array}{l}\text { Frailness of cervix } \\
\text { Present } \\
\text { Absent }\end{array}$ & $\begin{array}{l}8 \cdot 4(15 / 178) \\
4 \cdot 2(31 / 744)\end{array}$ & $\begin{array}{l}1.5(0.7-3 \cdot 2) \\
1.0\end{array}$ & 0.3 \\
\hline $\begin{array}{c}\text { Ectropion } \\
\text { Present } \\
\text { Absent }\end{array}$ & $\begin{array}{l}13 \cdot 5(7 / 52) \\
4.5(39 / 874)\end{array}$ & $\begin{array}{l}2 \cdot 6(1 \cdot 1-6 \cdot 5) \\
1 \cdot 0\end{array}$ & 0.04 \\
\hline
\end{tabular}

Analysis based on 863 routine clinic attenders and 63 sex workers. Data missing in up to five women. $95 \% \mathrm{CI}$ : $95 \%$ confidence interval.

Odds ratios and $\mathrm{p}$ values from multivariate logistic regression model adjusting for all variables listed. ures mentioned above. Overall, specificity would increase from $98 \cdot 3 \%$ to $99 \cdot 6 \%$, and the positive predictive value from $62.5 \%$ to $89.7 \%$. However, samples negative in both DFA and one-step PCR were not further analysed in nested PCR assays. Analysis of inhibiting components for the PCR assay showed inhibition in 9 of $168(5.4 \%)$ samples. Repeated testing of these 9 samples using a $100 \mu \mathrm{l}$ reaction mixture revealed the inhibition to be dilution dependant since 8 samples resulted in a 493 bp amplicon.

Prevalence of cervical chlamydia infection based on positivity in DFA and/or PCR was $4.3 \%$ among women examined in routine clinics as compared with $14 \cdot 3 \%$ among sex workers $(p=0.005)$. Risk factors for infection were further examined among routine clinic attenders. As shown in table 2, young age and use of oral contraception were the only statistically significant predictors for infection. Both in univariate and multivariate analysis, marital status, clinic location, clinic type, use of an intrauterine device, self-reported history of STD, literacy and housing conditions did not significantly influence the risk of infection $(p>$ $0.05)$. Women were also asked whether or not they had been with the same sexual partner during the past three months; however, $16 \%$ percent refused to answer this question. Among those who did answer there was no statistically significant difference between the small minority reporting more than one partner and those reporting a stable partner.

The association of symptoms and signs with the probability of chlamydial infection was also examined. Sixty-three percent of women complained of vaginal discharge ( $64 \%$ of routine clinic attenders as compared with $49 \%$ of sex workers, $p=0.03), 55 \%$ of abdominal pain $(56 \%$ versus $42 \%, \mathrm{p}=0.04$ ) and $38 \%$ of itching (39\% versus $27 \%, p=0.07)$. None of these symptoms were predictive of chlamydial infection. On examination, $69 \%$ were found to have abnormal vaginal discharge, $16 \%$ had mucopurulent discharge from the cervix, 33\% oedema of the cervix, $19 \%$ bled when taking the cervical specimen (cervical frailty) and $6 \%$ had some degree of ectropion. Prevalence of clinical signs was similar among routine clinic attenders and sex workers except for ectropion which was more frequent among sex workers $(27 \%$ as compared with $4 \%$ among routine clinic attenders, $p=0.0001$ ). In univariate analysis, mucopurulent cervical discharge $(p=$ $0.0001)$, frailness of the cervix $(p=0.03)$ and ectropion $(p=0.01)$ were all associated with the probability of infection. In multivariate analysis, however, only the presence of mucopus and ectropion were independently predictive of chlamydial infection (table 3 ).

\section{Discussion}

The advent of nucleic acid amplification techniques for the diagnosis of $C$ trachomatis infections has facilitated evaluation of antigen detection methods in situations when cell culture is not a feasible option. In ideal circumstances, PCR tests have been shown to be 
equally or more sensitive and specific than cell culture ${ }^{67}$ In the present study in Nicaragua, the DFA method had a sensitivity of $80 \%$ and a specificity of $98 \%$ when compared with a one-step PCR assay. Previous studies, using cell culture as the gold standard, have reported sensitivities between $60 \%$ and $81 \%$, and specificities in the range of $82 \%$ to $99 \% .^{12-15}$ However, in highly trained expert hands with a cut-off of just one elementary body, DFA testing can be more sensitive than culture. ${ }^{16}$ Taken together, these data illustrate the crucial role of the observer in DFA testing and indicate the absence of a definite gold standard for $C$ trachomatis.

In the present study a laboratory technician without previous experience in fluorescence microscopy was carefully trained. Although comparing well to the results from other studies, her performance may well be underestimated when DFA results are exclusively contrasted with one-step PCR testing. A surprisingly high number of DFA positive cases with a negative one-step PCR test was found predominantly in study locations where inadequate storage led to repeated thawing of samples. Repeated thawing and freezing is considered to be detrimental for the stability of DNA sequences. ${ }^{17}$ Unfortunately, dry ice or liquid nitrogen was not available at the time. The amount of intact DNA still present when tested by PCR may thus have been insufficient in a number of samples from these locations. Sensitivity and specificity was also higher among sex workers than among routine clinic attenders. As a consequence of repeated exposure, the antigen may have been present in higher concentrations among the latter. This interpretation is supported by the results from nested PCR assays whose sensitivity is enhanced compared with one-step assays. With the nested assays, ten out of 14 DFA positive cases were confirmed, leading to a considerably improved specificity and positive predictive value of the DFA test. Overall, $80 \%$ of discordant samples were confirmed as positive in the nested assays. These results should, however, be interpreted with caution because these assays were exclusively performed on discordant samples. Nested PCR systems suffer from the risk of cross-contamination leading to false positive results. This is, however, less likely in the present study since the two nested PCR assays used different target genes but gave completely concordant results. Taking these results into account would nevertheless overestimate the specificity and the positive predictive value of the DFA test.

In principle, DFA testing thus appears to be an adequate technique for the diagnosis of Chlamydia trachomatis in Nicaragua and other less developed countries. In a research context, validation by PCR or culture will often be necessary. In many settings these tests will have to be performed in an industrialised country. PCR analysis of frozen samples is valuable; however, much attention must be given to adequate storage and transport of samples in order to prevent thawing. In a recent study in Cape Verde, we found analysis of dried samples that can be kept at room temperature to be superior, allowing reliable detection of chlamydial antigen after more than 18 months of storage. ${ }^{18}$

It is noteworthy that the prevalence found in our study is considerably lower than that reported for urban populations in the neighbouring countries Honduras and $\mathrm{El}$ Salvador. ${ }^{19-21}$ Using a commercial EIA kit (Pharmacia Chlamydia EIA Test, Pharmacia, Sweden) a prevalence of $44 \%$ was reported for pregnant women in El Salvador, as compared with $28 \%$ for Salvadoranian women with cervicitis and $5 \%$ for asymptomatic women. These results, however, are quite unusual, indicating that there were problems with the test system which lead to false positive results. Indeed, in their study in Honduras, ${ }^{21}$ the same group reported that about $20 \%$ of samples had to be excluded because of high absorbance values in negative controls. Unfortunately, no systematic validation of these results using a different test system was performed. On the other hand, our results are similar to the findings from studies conducted in Panama, the Netherlands Antilles and Chile. The prevalence among women at high risk of infection in urban Panama ranged from $2 \%$ to $8 \% .^{22}$ Sixteen per cent of sex workers from Santiago de Chile and $5 \%$ of women attending gynaecological clinics on the Netherlands Antilles were found to be chlamydia positive. ${ }^{23} 24$

Our results will tend to underestimate the prevalence of genital chlamydia infection among Nicaraguan women. It has been stated that "the more you look" (for genital chlamydia infection) "the more you find" ${ }^{16}$ For example, by testing both samples from the cervix and the urethra, the yield is increased by $10 \%$ to $20 \%$. Furthermore, as discussed above, it is clear that neither method used in this study was $100 \%$ sensitive. Although a lower cut-off value for the DFA test would not have improved performance in comparison with the one-step PCR, it is very likely that at least some of the samples with less than ten EBs stemmed from women with cervical infection.

Young age, use of oral contraceptives and commercial sex work were the risk factors for chlamydial infection identified in this study. Multiple sexual partners, unmarried status and low socio-economic position have also been shown to predict infection. ${ }^{2}$ In the present study, a substantial proportion of routine clinic attenders refused to answer the question regarding multiple sexual partners and no statistically significant association with their marital status was evident. Both findings may be related to the concept of machismo which is central in defining sexual relations in Nicaragua and other Latin countries. ${ }^{25}$ In men, machismo values encourage early sexual initiation and multiple sexual conquests, while repressing sexual autonomy in women. Marital status of the woman may thus be an imprecise proxy measure for the sexual behaviour of her husband. The study population was relatively homogeneous with regard to socio-economic status. Women of higher social standing generally do not attend public 
health centres but consult private clinics. This may explain the absence of an association with socio-economic factors. Our study confirms the clinical signs that are generally found to be associated with chlamydial infection of the cervix. $^{2}$ The strongest association was found with mucopurulent discharge from the cervix, thus supporting the use of this symptom in the syndromic algorithm for the management of vaginal discharge that is recommended by the World Health Organisation (WHO) ${ }^{26}$

Our findings have important implications for STD control in Nicaragua. Both among women attending routine clinics and among female sex workers, the prevalence of chlamydial infection is considerably higher than gonorrhoea. $^{27}$ However, the importance of chlamydial infections is not yet widely appreciated. Benzathine penicillin is still frequently used as the exclusive treatment in case of mucopurulent cervicitis although this is of questionable value for gonorrhoea and ineffective for chlamydial infection. ${ }^{26} 28$ The high prevalence among young women would justify generalised screening in antenatal and other routine clinics; however, considering the lack of trained personnel, and the limited laboratory facilities and funds in a country facing many other health problems, this is not an option at present. The implementation of syndrome based treatment algorithms, adapted to the Nicaraguan context, should, however, be given serious consideration. Although in women such algorithms will miss a considerable proportion of cases while leading to unnecessary treatments in others, ${ }^{29}$ we have observed a substantial decline in STD rates among sex workers following the implementation of algorithms together with a health education and condom promotion programme. ${ }^{30}$ Unfortunately, official STD treatment guidelines do not follow a syndrome based approach. ${ }^{31}$ In Nicaragua, there is a threat of an epidemic of heterosexually transmitted human immunodeficiency virus (HIV) infections. $^{32}$ In a large randomised community intervention trial in Tanzania, an intervention including syndromic STD management, continuous availability of drugs and health education has recently been shown to substantially reduce the incidence of HIV infections. ${ }^{33}$ In Nicaragua, levels of STD and HIV related knowledge and condom use are still low, and particularly low among young people and young women. ${ }^{34}$ Health education programmes in and out of school along with improvements in the management of patients with sexually transmitted diseases are urgently needed in Nicaragua.

We are grateful to all the women who participated in this study. We also thank all the medical staff of the clinics involved. Special thanks are due to Reyna Castro (León), Marc Isler (Bluefields), Gioconda Espinoza (Corinto), Karin Volken (Matagalpa), and Ulla Zettersten (Uppsala). This study was supported by the AIDS Task Force of the European Switzerland and Gruppe für Entwicklungszusammenarbeit (GEAB), Basle, Switzerland.

1 Schachter J. Epidemiology of Chlamydia trachomatis infections. In: Bowie WR, Caldwell HD, Jones RP, et al, eds. Chlamydial infections. Cambridge: Cambridge University Press, 1990:545-54.
2 Cates W, Wasserheit JN. Genital chlamydial infections: epidemiology and reproductive sequelae. Am $\mathcal{f}$ Obstet Gynecol 1991;164:1771-81.

3 Schachter J, Stoner M, Moncada J. Screening for chlamydial infections in women attending family planning clinics. West f Med 1983;138:375-9.

4 Stamm WE, Koutsky LA, Benedetti JK, Jourden JL, Brunham RC, Holmes KK. Chlamydia trachomatis urethral infections in men. Prevalence, risk factors, and clinical manifestations. Ann Int Med 1984;100:47-51.

5 Taylor-Robinson D, Thomas BJ. Laboratory techniques for the diagnosis of chlamydial infections. Genitourin Med 1991;67:256-66.

6 Taylor-Robinson D. The value of non-culture techniques for diagnosis of Chlamydia trachomatis infections: making the best of a bad job. Eur $\mathcal{F}$ Clin Microbiol Infect Dis the best of a bad

7 Mahony JB, Luinstra KE, Sellors JW, et al. Role of confirmatory PCRs in determining performance of Chlamydia Amplicor PCR with endocervical specimens from women with a low prevalence of infection. F Clin Microbiol 1994;32:2490-3.

8 Egger M, Pauw J, Ferrie J, Isler M, Gorter A, Davey Smith G. An action research project to reduce sexual transmission of HIV and population AIDS risk in Nicaragua. Technical report for the year 1991. London: Department of Epidemiology and Public Health, University College London, 1992.

9 Ossewaarde JM, Rieffe M, Rozenberg-Arska M, Ossenkoppele PM, Nawrocki RP, van Loon AM. Ossenkoppele PM, Nawrocki RP, van Loon AM. chain reaction test for detection of Chlamydia trachomatis. chain reaction test for detection of

10 Comanducci M, Ricci S, Ratti G. The structure of a plasmid of Chlamydia trachomatis believed to be required for growth within mammalian cells. Mol Microbiol 1988;2:531-8.

11 Wahlberg J, Lundeberg J, Hultman T, Uhlén M. General colorimetric method for DNA diagnostics allowing direct solid-phase genomic sequencing of the positive samples. Proc Natl Acad Sci USA 1990;87:6569-73.

12 Forbes BA, Bartholoma N, McMillan J, Roefaro M, Weiner L, Welych L. Evaluation of a monoclonal antibody test to detect chlamydia in cervical and urethral specimens. F Clin Microbiol 1986;23:1 136-7.

13 Lipkin ES, Moncada JV, Shafer MA, Wilson TE Schachter J. Comparison of monoclonal antibody staining and culture in diagnosing cervical chlamydial infection. $\mathcal{F}$ Clin Microbiol 1986;23:114-7.

14 Hipp SS, Han Y, Murphy D. Assessment of enzyme immunoassay and immunofluorescence tests for detection of Chlamydia trachomatis. $\mathcal{f}$ Clin Microbiol 1987;25: 1938-43.

15 Kent GP, Harrison HR, Berman SM, Keenlyside RA. Screening for Chlamydia trachomatis infection in a sexually transmitted disease clinic: comparison of diagnostic tests with clinical and historical risk factors. Sex Transm Dis $1988 ; 15: 51-7$.

16 Hay PE, Thomas BJ, Horner PJ, MacLeod E, Renton AM, Taylor-Robinson D. Chlamydia trachomatis in women: the more you look, the more you find. Genitourin Med 1994;70:97-100.

17 Rolfs A, Schuller I, Finckh U, Weber-Rolfs I. PCR: clinical diagnostics and research. Berlin: Springer Verlag, 1992:1-21.

18 Herrmann B, Nyström T, Wessel H, Moniz F, Bergström $\mathrm{S}$. Detection of Neisseria gonorrhoeae in pregnant women in Cape Verde: comparison between Amplicor and an in Cape Verde: comparison between Amplicor and an inhouse polymerase chain reaction assay. Eleventh meeting of the International Society for STD
Orleans August 27-30, 1995:abstract 340 .

19 Cañas Posada AB, Jonasson J, de Linares L, Bygdeman S. Prevalence of urogenital Chlamydia trachomatis infection in El Salvador: II. Gynaecology outpatients. Int $\mathcal{f} S T D$ AIDS 1992;3:434-6.

20 Cañas Posada AB, Jonasson J, de Linares L, Bygdeman S. Prevalence of urogenital Chlamydia trachomatis infection in El Salvador. I. Infection during promancy and perinatal transmission. Int $\mathcal{f} S T D$ AIDS 1992;3: 33-7.

21 Venegas VS, Villafranca P, Madrid JP, Cosenza $H$, Bygdeman S. Gonorrhoea and urogenital chlamydial infection in female prostitutes in Tegucigalpa, Honduras. int $\mathcal{F}$ STD AIDS 1991;2:195-9.

22 Reeves WC, Quiroz E. Prevalence of sexually transmitted diseases in high-risk women in the republic of Panama. Sex Transm Dis 1987;14:69-74.

23 Asin JD, Nahorst RR, Thijs CT, Assendelft WJ, Hooi BR Routine testing for Chlamydia trachomatis on Curacao, Netherlands Antilles. Am $\mathcal{f}$ Obstet Gynecol 1993;169: 375-8.

24 Martínez MA, Pinto ME, Arroyave R. Incidencia de infección cervical por Chlamydia trachomatis y Mycoplasma urogenitalis en un consultorio de enfermedades de transmisión sexual. Rev Med Chil 1986;114:118-22.

25 Carrier JM. Sexual behavior and spread of AIDS in Mexico. Med Anthropol 1989;10:129-42.

26 WHO Study Group on Management of Sexually Transmitted Diseases Patients. Management of patients with sexually transmitted diseases: report of a WHO Study Group. WHO Technical Report Series 810. Geneva: World Health Organization, 1991

27 Espinoza F, Egger M, Herrmann B, Isler M, Volken K, Davey Smith G. STD in Nicaragua: population rate esti- 
mates and health seeking behaviour. IXth International Conference on AIDS, Berlin 6-11 June, 1993:abstract PO-C06-2702.

28 Castro I, Bergeron MG, Chamberland S. Characterization of multiresistant strains of Neisseria gonorrhoeae isolated in Nicaragua. Sex Transm Dis 1993;20:314-20.

29 Espinoza F, Herrmann B, Egger M, Isler M, Volken K, Davey Smith G. World Health Organisation treatment protocol for vaginal discharge: how effective in Nicaragua? IXth International Conference on

30 Rivera R, Egger M, Paniagua M, Volken K, Davey Smith G. HIV/STD prevention among sex workers in Nicaragua. Xth International Conference AIDS, Yokohama 7-12 August, 1994:abstract 362C.
31 Programa Nacional de Prevención y Control de las ETS/VIH/SIDA. Manual de Programa de Control $y$ Prevención de las ETS/VIH/SIDA. Managua: Ministerio de Salud, 1994.

32 Low N, Egger M, Gorter A, et al. AIDS in Nicaragua: epidemiological, political and sociocultural perspectives. Int $\mathcal{F}$ Health Services 1993;23:685-702.

33 Grosskurth H, Mosha F, Todd J, et al. Impact of improved treatment of sexually transmitted diseases on HIV infection in rural Tanzania: randomised controlled trial. Lancet 1995;346:530-6.

34 Egger M, Ferrie J, Gorter A, et al. HIV/AIDS related knowledge, attitudes and practices among Managuan secondary school student. Bull Panam Health Org 1993;27:360-9. 